\title{
Modeling Spatial Patterns of Humus Forms in Montane and Subalpine Forests: Implications of Local Variability for Upscaling
}

\author{
Niels Hellwig ${ }^{1,2,3, *(\mathbb{D})}$, Dylan Tatti ${ }^{4,5}$ (D) , Giacomo Sartori ${ }^{6}$, Kerstin Anschlag ${ }^{1}$, Ulfert Graefe ${ }^{7}$, \\ Markus Egli ${ }^{8}$, Jean-Michel Gobat ${ }^{4}$ and Gabriele Broll ${ }^{1}$ \\ 1 Institute of Geography, Osnabrück University, Seminarstraße 19ab, 49074 Osnabrück, Germany; \\ kerstin.anschlag@uni-osnabrueck.de (K.A.); gabriele.broll@uni-osnabrueck.de (G.B.) \\ 2 Institute of Earth and Environmental Science, Potsdam University, Karl-Liebknecht-Straße 24-25, \\ 14476 Potsdam, Germany \\ 3 Faculty of Business Management and Social Sciences, Osnabrück University of Applied Sciences, \\ Caprivistraße 30a, 49076 Osnabrück, Germany \\ 4 Functional ecology laboratory, University of Neuchâtel, Rue Emile-Argand 11, 2000 Neuchâtel, Switzerland; \\ dylan.tatti@bfh.ch (D.T.); Jean-Michel.Gobat@unine.ch (J.-M.G.) \\ 5 Division Agronomie, Haute école des sciences agronomiques, forestières et alimentaires HAFL, Länggasse \\ 85, 3052 Zollikofen, Switzerland \\ 6 Museo Tridentino di Scienze Naturali, Corso del Lavoro e della Scienza 3, 38122 Trento, Italy; \\ giacomo.sartori@sfr.fr \\ 7 IFAB Institut für Angewandte Bodenbiologie GmbH, Tornberg 24a, 22337 Hamburg, Germany; \\ ulfert.graefe@ifab-hamburg.de \\ 8 Department of Geography, University of Zürich, Winterthurerstrasse 190, 8057 Zurich, Switzerland; \\ markus.egli@geo.uzh.ch \\ * Correspondence: niels.hellwig@uni-potsdam.de; Tel.: +49-541-969-2033
}

Received: 1 November 2018; Accepted: 19 December 2018; Published: 21 December 2018

check for updates

\begin{abstract}
Humus forms are a distinctive morphological indicator of soil organic matter decomposition. The spatial distribution of humus forms depends on environmental factors such as topography, climate and vegetation. In montane and subalpine forests, environmental influences show a high spatial heterogeneity, which is reflected by a high spatial variability of humus forms. This study aims at examining spatial patterns of humus forms and their dependence on the spatial scale in a high mountain forest environment (Val di Sole/Val di Rabbi, Trentino, Italian Alps). On the basis of the distributions of environmental covariates across the study area, we described humus forms at the local scale (six sampling sites), slope scale (60 sampling sites) and landscape scale (30 additional sampling sites). The local variability of humus forms was analyzed with regard to the ground cover type. At the slope and landscape scale, spatial patterns of humus forms were modeled applying random forests and ordinary kriging of the model residuals. The results indicate that the occurrence of the humus form classes Mull, Mullmoder, Moder, Amphi and Eroded Moder generally depends on the topographical position. Local-scale patterns are mostly related to micro-topography (local accumulation and erosion sites) and ground cover, whereas slope-scale patterns are mainly connected with slope exposure and elevation. Patterns at the landscape scale show a rather irregular distribution, as spatial models at this scale do not account for local to slope-scale variations of humus forms. Moreover, models at the slope scale perform distinctly better than at the landscape scale. In conclusion, the results of this study highlight that landscape-scale predictions of humus forms should be accompanied by local- and slope-scale studies in order to enhance the general understanding of humus form patterns.
\end{abstract}


Keywords: soil organic matter decomposition; spatial modeling; random forest; multi-scale analysis; forest soils; Italian Alps

\section{Introduction}

Humus forms are a distinctive morphological indicator of soil organic matter decomposition, since they integrate both the sequence of organic horizons $(\mathrm{OL}=$ litter, $\mathrm{OF}=$ fragmented residues, $\mathrm{OH}$ $=$ humified residues) above the mineral soil and the soil structure in the mineral soil as a result of soil biological activities [1-3]. Hence, the spatial arrangement of humus forms corresponds to spatial patterns of soil ecological processes. In montane and subalpine forests, this relationship has been recently investigated for microannelid assemblages, microbial communities, and chemical properties of the topsoil [3-6].

From the local to the landscape scale, different factors and processes influence spatial soil ecological patterns $[7,8]$. Study areas in the high mountains were found to be characterized by a high small-scale variability of humus forms related to micro-topography and local ground cover differences [9-11]. At the landscape scale, environmental factors such as climate, relief, parent material, vegetation, and land use shape landscape units with different humus systems [12-15]. In mountain environments with similar geological conditions, relief is the most decisive factor, as it controls mesoclimate, hydrological processes, erosion dynamics and vegetation zones [16-18].

Spatial patterns of soil properties are frequently predicted by applying quantitative modeling methods [19]. Spatial modeling often relies on geostatistical methods [20] or on modeling soil-landscape relationships [21,22]. Numerous studies have applied spatial modeling of soil properties from the farm or regional scale [23] up to the global scale (e.g., [24-26]).

Mountain areas are characterized by a complex terrain. Therefore, geostatistical approaches are not that suitable to model the variability of soil properties. Recent studies have demonstrated that an investigation of the soil-landscape interrelationship is more promising for modeling and predicting patterns related to soil organic matter decomposition in montane and subalpine forests $[3,6,27,28]$. These studies focused either on the slope or on the landscape scale. However, the relationship between the spatial scale and soil ecological patterns remained unclear. In order to enhance the understanding of the interplay of environmental influences and soil organic matter decomposition processes in montane and subalpine forests, detailed, complementary cross-scale analyses are required.

The aim of this study was to examine the spatial patterns of humus forms and their dependence on the spatial scale in montane and subalpine forests of the Italian Alps. We addressed the following research questions:

- Which spatial patterns of humus forms occur at the local scale? Does the local variability coincide with local site factors, especially vegetation cover?

- What are the main influencing factors of humus form patterns at the slope and the landscape scale?

- How do spatial models combining random forest with ordinary kriging of the model residuals perform depending on the spatial scale?

\section{Materials and Methods}

\subsection{Study Area}

The study area includes the valleys Val di Sole, Val di Rabbi, Val di Peio and Val di Vermiglio, located in the Italian Alps (Autonomous Province of Trento) (Figure 1). The dominant parent materials are paragneiss, schist and phyllite, all yielding acidic weathering products $[27,29,30]$. Spatial patterns of mesoclimate and soil properties are related to the highly variable mountain topography. Mean annual air temperature varies between $2{ }^{\circ} \mathrm{C}$ at the tree line and $8{ }^{\circ} \mathrm{C}$ at the lower slopes of Val di Sole [31]. 


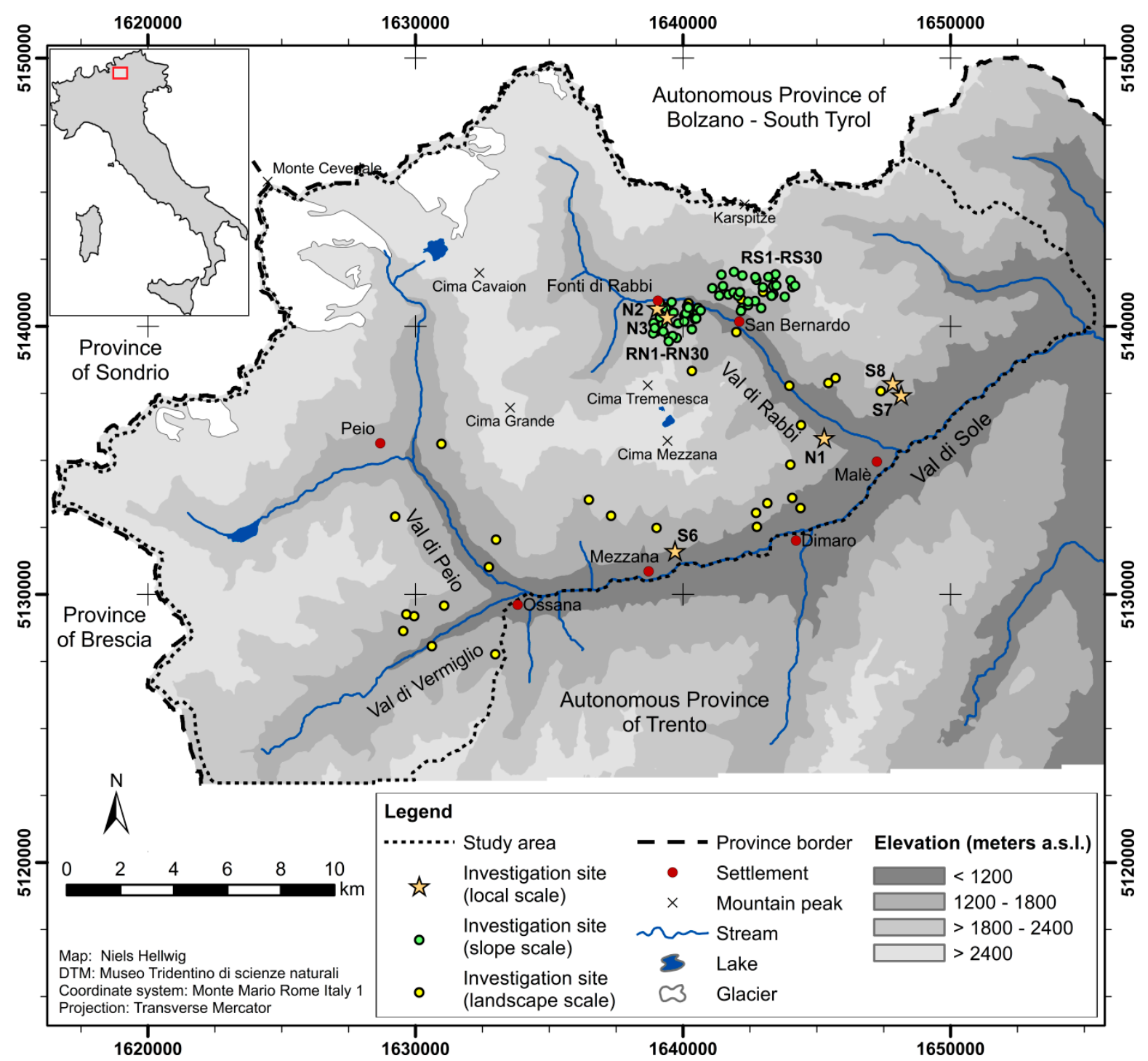

Figure 1. Study area and sampling sites (modified from [30]). Investigation sites are designated as N1-N3 (north-facing slopes) and S6-S8 (south-facing slopes) at the local scale and RN1-RN30 (north-facing slope) and RS1-RS30 (south-facing slope) at the slope scale.

All investigations in this study refer to the forested valley slopes within the study area (ca. 800-2200 $\mathrm{m}$ a.s.1.). Figure S1 shows the distribution of forest tree species within the study area. The main tree species of these forests are European larch (Larix decidua Mill.) and Norway spruce (Picea abies (L.) H.Karst.). From ca. $1900 \mathrm{~m}$ a.s.l. up to the tree line, Entic Podzols, Albic Podzols and Umbric Podzols are the main soil classes, whereas the forests below are characterized by Haplic Cambisols (Dystric) and Umbric Podzols ([32], according to [33]).

\subsection{Experimental Design}

We analyzed humus forms at three different spatial scales on the basis of three sets of investigation sites (Figure 1). Humus forms were classified as described by Hellwig et al. [3] according to Ad-hoc-AG Boden [34] and Graefe [35]. Similar to other international humus form classifications (e.g., [36-38]), this approach relies on the characterization of organic layers above the mineral soil and of the biogenic soil structure in the mineral soil (details are given in Reference [3]).

At the local scale, we investigated six sampling sites located at three different elevation levels (approximately $1200 \mathrm{~m}, 1400 \mathrm{~m}$ and $1630 \mathrm{~m}$ a.s.l.) at north-facing slopes (N1-N3) and at south-facing slopes (S6-S8) (Figure 1). These sites have been selected and described in detail for previous soil 
ecological studies (e.g., [6,39]). The ground cover at these sites was highly variable, with areas differently characterized by litter, grass, fern, moss, and branches (Figure 2). Patterns of ground cover types were in part due to local variations in relief (distribution of soil moisture and distribution of areas of erosion and accumulation) and in forest structure (distribution of light and shadow). At each sampling site, several samples were analyzed according to the occurrence of ground cover types within an area of $25 \mathrm{~m} \times 25 \mathrm{~m}$ (Figure 3). Humus forms at the local scale were sampled in the summers of 2013 and 2014.

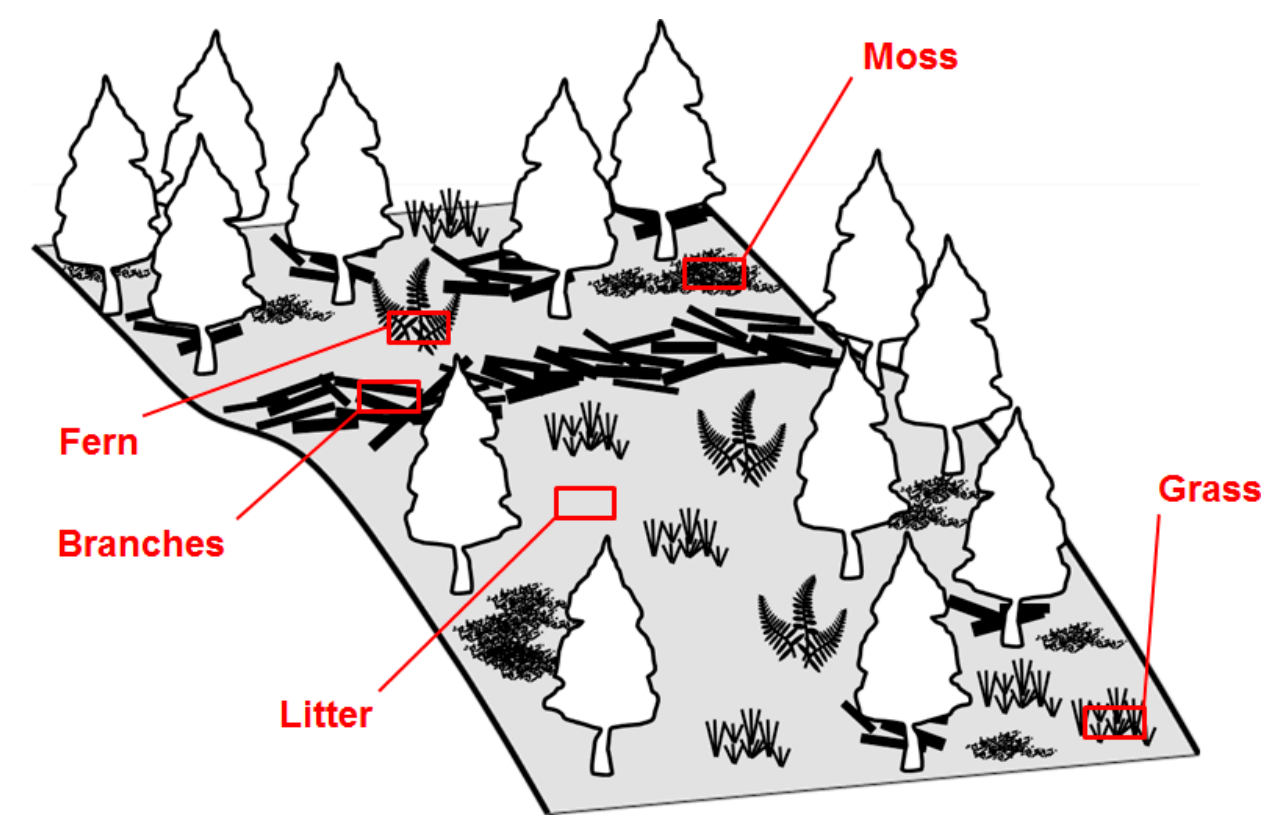

Figure 2. Spatial heterogeneity of investigation sites and examined ground cover types.

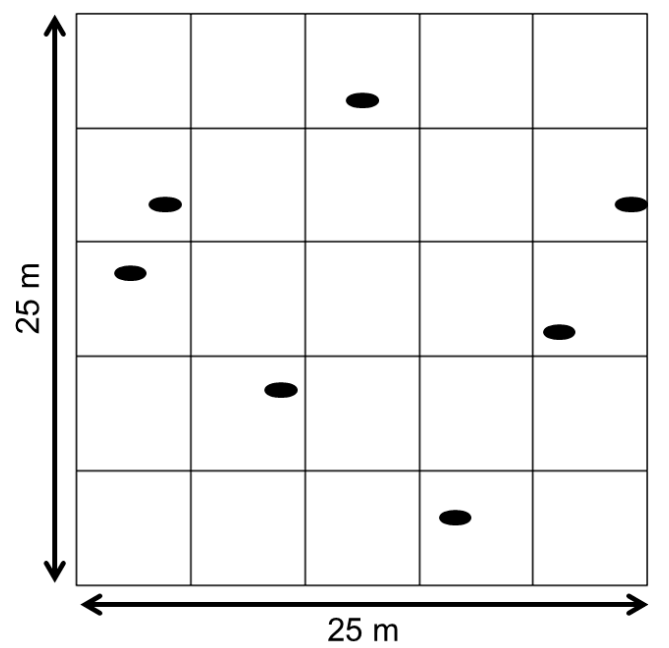

Humus form profile

Figure 3. Example of the distribution of humus form profiles at the local scale (modified from Reference [30]).

At the slope scale, we built upon the humus form analyses by Hellwig et al. [3] with reference to 60 sampling sites: Both 30 sites on a north-facing slope (RN1-RN30) and on a south-facing slope (RS1-RS30) in Val di Rabbi (Figure 1). The north-facing slope covers sites between the west slope exposure $\left(-90^{\circ}\right)$ and the east exposure $\left(90^{\circ}\right)$ with a mean exposure of $2^{\circ}$; the south-facing slope covers sites between the south-east slope exposure $\left(135^{\circ}\right)$ and the west exposure $\left(270^{\circ}\right)$ with a mean exposure of $204^{\circ}$. The mean slope angles are between $38^{\circ}$ and $39^{\circ}$ in both datasets (value range between $25^{\circ}$ 
and $60^{\circ}$ ). At the landscape scale, we investigated 30 additional sites across the study area (Figure 1). These sites covered an optimized sample of combinations of environmental conditions as determined with conditioned Latin Hypercube Sampling ([11], according to Reference [40]). Humus forms at the slope and landscape scale were sampled in the summer of 2015. Table S1 shows raw data at the landscape scale.

\subsection{Spatial Analysis}

We analyzed the frequencies of humus form classes for each present ground cover type based on all samples per investigation site. At the local scale, this provides information on the spatial variability of dominant humus forms as related to ground vegetation and micro-topography.

At the slope scale, we built upon the model results by Hellwig et al. [3] referring to the two main characteristics of humus forms: (a) Presence of organic layers above the mineral soil and (b) biogenic soil structure in the mineral soil. We reclassified these results to predict the occurrence of humus form classes according to Table 1.

Table 1. Predicted humus form classes as reclassified from relative values representing the predicted presence of organic layers above the mineral soil and the predicted biogenic soil structure in the mineral soil (according to Reference [3]).

\begin{tabular}{ccc}
\hline Predicted Humus Form Class & $\begin{array}{c}\text { Presence of Organic Layers } \\
\text { above Mineral Soil }\end{array}$ & $\begin{array}{c}\text { Biogenic Soil Structure in the } \\
\text { Mineral Soil }\end{array}$ \\
\hline Moder & $>0.75$ & $<0.25$ \\
\hline Moder, partially eroded & $\geq 0.25$ and $\leq 0.75$ & $<0.25$ \\
\hline Eroded Moder & $<0.25$ & $<0.25$ \\
\hline Moder, trend to Amphi & $>0.75$ & $\geq 0.25$ and $\leq 0.75$ \\
\hline Mullmoder & $\geq 0.25$ and $\leq 0.75$ & $\geq 0.25$ and $\leq 0.75$ \\
\hline Mullmoder, eroded & $<0.25$ & $>0.75$ \\
\hline Amphi & $>0.75$ & $>0.75$ \\
\hline Mull, trend to Amphi & $\geq 0.25$ and $\leq 0.75$ & $>0.75$ \\
\hline Mull & $<0.25$ &
\end{tabular}

Spatial modeling at the landscape scale was based on the same approach as at the slope scale [3]. We combined a random forest [41] with ordinary kriging of the model residuals [20] to analyze the presence of organic layers above the mineral soil and the biogenic soil structure in the mineral soil. Random forest is a commonly used modeling technique to analyze complex non-linear relationships between spatial patterns of a target variable and environmental influencing factors, for example soil-landscape relationships (e.g., [42-44]). However, random forest models are limited in explaining soil-ecological patterns [3]; thus, we used ordinary kriging of the model residuals to account for the unexplained part of spatial soil-ecological patterns. The modeled areas comprised the closed coniferous forests on siliceous bedrock inside the study area. The factors considered for spatial modeling are summarized in Table 2. The mean values of the squared model residuals and explained variances of the model were calculated to evaluate the performance of the random forest models [45]. Spatial modeling was implemented with the statistical software $R$ (version 3.4.0) [46] and the R package "randomForest" [45]. Model results were reclassified to humus form classes as at the slope scale (Table 1). 
Table 2. Environmental variables used as factors for modeling at the landscape scale.

\begin{tabular}{|c|c|c|}
\hline Factor & Method Reference & Data Source \\
\hline Elevation a.s.l. & & \multirow{14}{*}{$\begin{array}{l}\text { Digital terrain model, grid width } 10 \mathrm{~m} \text { ([27], } \\
\text { provided by Museo Tridentino di Scienze } \\
\text { Naturali) }\end{array}$} \\
\hline Slope & \multirow{5}{*}{ Zevenbergen \& Thorne [47] } & \\
\hline Slope exposure & & \\
\hline Profile curvature & & \\
\hline Planform curvature & & \\
\hline General curvature & & \\
\hline Insolation & Böhner \& Antonic [48] & \\
\hline SAGA wetness index & Böhner et al. [49] & \\
\hline LS factor & Moore et al. [50] & \\
\hline $\begin{array}{l}\text { Overland flow distance to } \\
\text { channel network }\end{array}$ & Freeman [51] & \\
\hline \multicolumn{2}{|l|}{$\begin{array}{l}\text { Vertical distance to channel } \\
\text { network }\end{array}$} & \\
\hline Mass balance index & Friedrich [52] & \\
\hline \multicolumn{2}{|l|}{ Mid-slope position } & \\
\hline \multicolumn{2}{|l|}{ Normalized height } & \\
\hline Forest type & & \multirow{2}{*}{$\begin{array}{l}\text { Forest inventory data, provided by Provincia } \\
\text { Autonoma di Trento, Servizio Foreste e Fauna }\end{array}$} \\
\hline Forest density & & \\
\hline
\end{tabular}

\section{Results}

The results regarding the relationship between humus forms and ground cover types at the local scale are listed in Table 3. Moder humus forms prevailed at sites N2 and N3 regardless of the ground cover type (north-facing slope, $1400 \mathrm{~m}$ and $1630 \mathrm{~m}$ a.s.l.). At site N1 (north-facing slope, $1200 \mathrm{~m}$ a.s.l.), there was a mosaic of Mull, Moder and Eroded Moder. Mull was related to spots covered with fern or moss vegetation, whereas Moder was related to litter spots (partially Eroded Moder) and to spots with accumulation of branches. Mull, Amphi and Mullmoder were the dominant humus forms at sites S6 and S7 (south-facing slope, $1200 \mathrm{~m}$ and $1400 \mathrm{~m}$ a.s.l.). At site S8, spots covered with grass/moss or characterized by accumulation of branches exhibited Moder humus forms, whereas Mullmoder humus forms dominated litter spots, which were more related to erosion processes. The relationship between the micro-topography, the ground cover type and the small-scale variability of humus forms is illustrated in Figure 4 by example of site S8.

The predicted patterns of humus form classes at the slope scale (as reclassified from the predicted presence of organic layers above the mineral soil and biogenic soil structure in the mineral soil based on Table 1) illustrate a dominance of Moder on the north-facing slope, especially above $1500 \mathrm{~m}$ a.s.l. The frequency of Amphi increases from higher to lower parts of the north-facing slope. On the south-facing slope, Mull and Amphi are dominant at low elevation, whereas Moder and Mullmoder prevail at high elevation. Additionally, humus forms characterized by erosion are predicted at some places of both slopes (Figure 5, see also Table S3). 
Table 3. Humus form classes at different ground cover types at the local scale (sites N1-N3 and S6-S8). See Table 2 for raw data.

\begin{tabular}{cccc}
\hline Site & Ground Cover & Sample Size & $\begin{array}{c}\text { Dominant Humus Form } \\
\text { Classes (according to [3]) }\end{array}$ \\
\hline N1 & Fern & 3 & Mull \\
& Moss & 4 & Mull \\
& Litter & 2 & Moder, Eroded Moder \\
& Branches & 3 & Moder \\
\hline N2 & Moss & 4 & Moder \\
& Litter & 2 & Moder \\
& Branches & 1 & Moder \\
\hline N3 & Grass & 4 & Moder \\
& Moss & 3 & Moder \\
& Litter & 1 & Moder \\
& Branches & 1 & Moder \\
\hline S6 & Grass & 4 & Amphi \\
& Litter & 4 & Mull \\
& Branches & 2 & Amphi, Mullmoder \\
& Grass & 5 & Mull, Amphi, Mullmoder \\
\hline S7 & Litter & 3 & Moder \\
& Grass/Moss & 5 & Mullmoder \\
\hline S8 & Litter & 5 & Moder \\
& Branches & 1 & \\
& & &
\end{tabular}

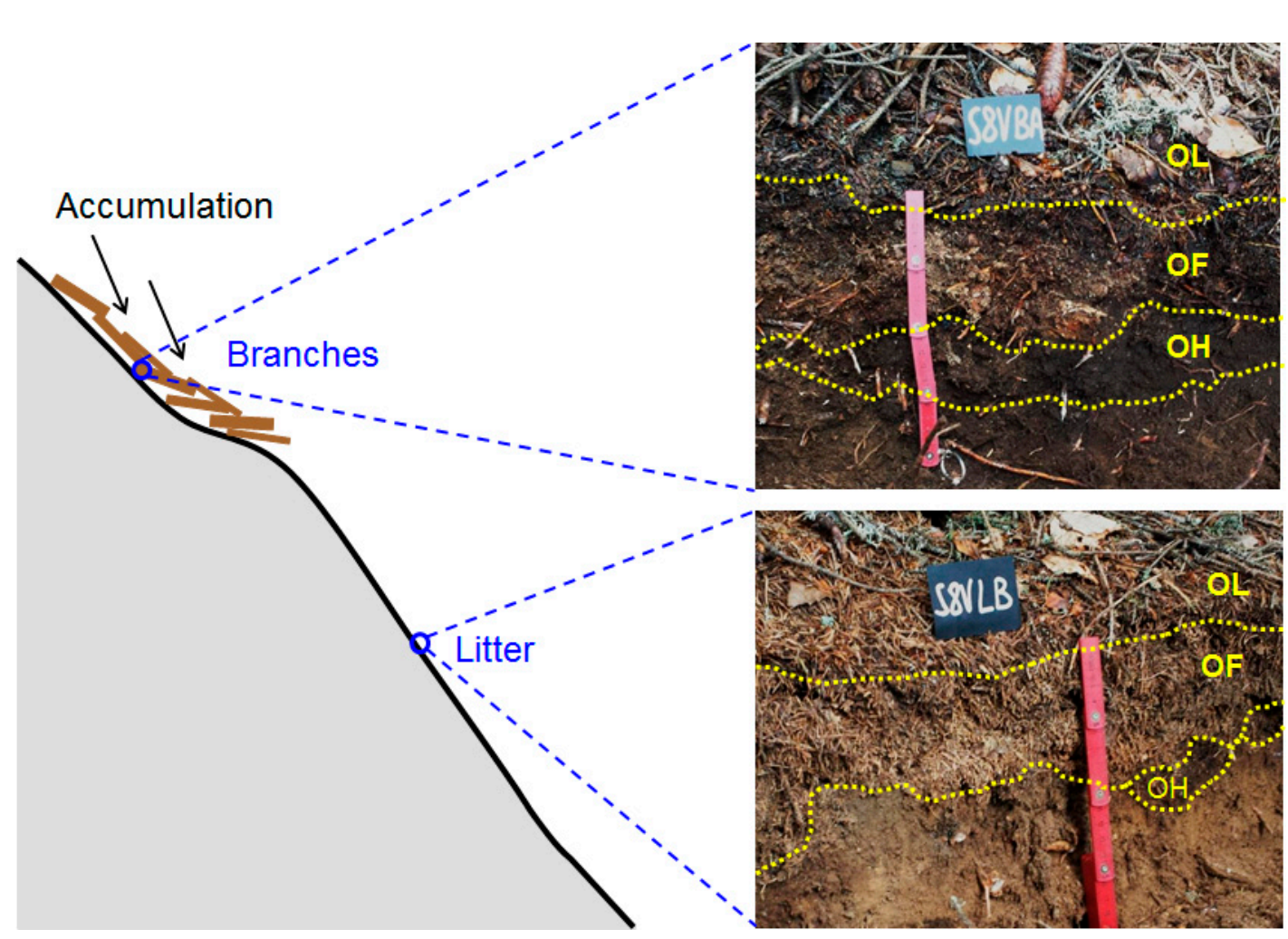

Figure 4. Variability of humus forms as correlated with local accumulation and erosion sites. The photos provide an example from site S8. Top: Moder profile under branches. Bottom: Mullmoder profile under litter. 


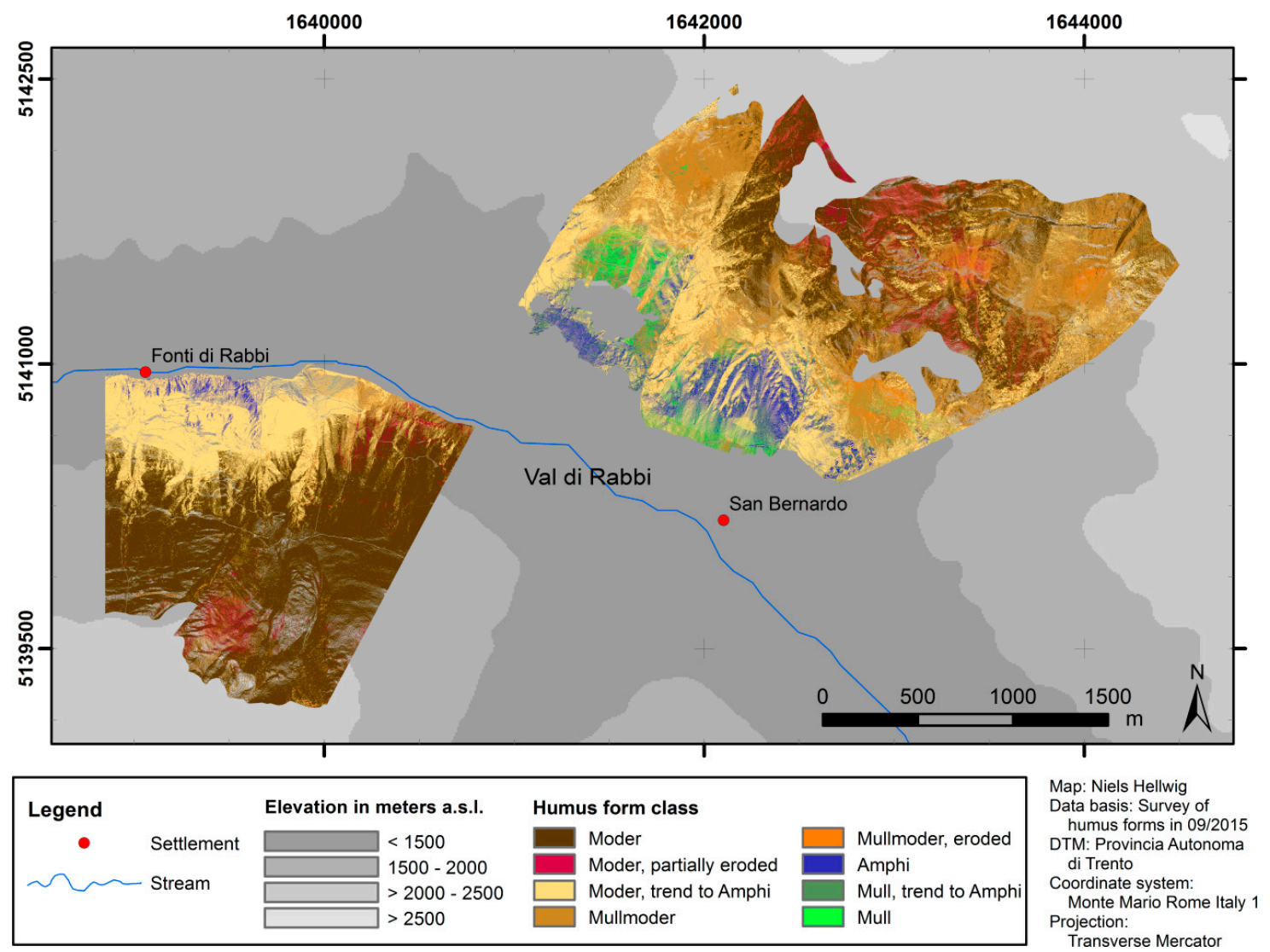

Figure 5. Predicted humus form classes at the slope scale.

Figure 6 displays the predicted patterns of humus form classes at the landscape scale. The most dominant predicted classes are Mullmoder and Moder, mostly with trend to Amphi. Mull and Amphi spots are rare and occur mostly at low elevation close to the valley bottoms, especially on south-facing slopes. The underlying model predictions of the presence of organic layers above the mineral soil and of the biogenic soil structure in the mineral soil (based on random forest plus kriging of the model residuals) are given in Figures S2 and S3. The evaluation of the random forest models (i.e., before kriging of the model residuals) yielded 0.18 (presence of organic layers above the mineral soil) and 0.23 (biogenic soil structure in the mineral soil) as mean values of the squared residuals and explained variances of $6 \%$ (presence of organic layers above the mineral soil) and $8 \%$ (biogenic soil structure in the mineral soil). Figure S4 shows the variograms used for kriging of the residuals.

\section{Discussion}

Despite the increasing research focus on the transfer of soil information between different spatial scales using upscaling and downscaling methods (e.g., [53,54]), the effects of the spatial scale on soil ecological patterns have been examined by only a few previous studies [7,8]. Levin [55] elucidated that spatial ecological patterns are autocorrelated up to a specific correlation length, which is caused by variations of different influencing factors and mechanisms depending on the spatial scale. The results of this study show that also spatial patterns of humus forms are influenced by different environmental factors from the local scale to the landscape scale.

Local-scale patterns of organic matter decomposition (from sites N1-N3 and S6-S8) are characterized both by a tendency to a higher dominance of Moder from south-exposed to north-exposed sites and by a high variability that is related to the local variation of ground cover and to micro-topography (Table 3). At spots of branches (accumulation/deposition of material along the slope), there is generally more accumulation of organic matter (Moder, Amphi) compared to litter spots (rather erosive to stable conditions along the slope facilitating formation of Mullmoder, Mull 
or Eroded Moder). Those spots where deadwood accumulates can be studied in more detail by differentiating lignoforms, which have recently been introduced as humus forms characterized by deadwood decay [56]. The observed local effects of ground vegetation and micro-topography on patterns of organic matter decomposition and humus forms are in line with previous studies from mountainous areas $[9,10,57]$. The findings by Anschlag et al. [11] showed that patterns of humus forms in the coniferous forests of the study area are generally more related to small-scale mosaics in the vegetation structure of the herb layer than to forest tree species.

Predicted patterns of humus forms at the slope scale are characterized by an increasing presence of Moder instead of Mull and Amphi from south exposure to north exposure and from low to high elevation (Figure 5). Thus, these patterns reflect a tendency of increasing organic matter accumulation and concurrently decreasing bioturbation in the topsoil from potentially warmer to colder spots across the valley. These findings correspond with the results from previous studies that addressed topoclimatic effects on organic matter decomposition including humus forms, soil mesofauna, microbiological and biochemical soil properties [5,6,12,27,58]. However, Egli et al. [59] found that the decomposition rate below $1700 \mathrm{~m}$ a.s.l. was higher on north-facing slopes than on south-facing slopes, as decomposition on the lower parts of the slopes was limited by soil moisture. Furthermore, humus form patterns at the slope scale were shown to be related to curvature, slope angle, and forest type [60].

At the landscape scale, the humus form classes Mullmoder and Moder with trend to Amphi are dominant throughout the study area (Figure 6). In fact, the relationship between humus form patterns and topography is also visible in the predictions at the landscape scale, but less marked than at the slope scale. This may be partly due to additional factors that are related to landscape-scale patterns, e.g. different former land-use practices [61]. However, the dominance of intermediate classes between Moder, Mull and Amphi (Mullmoder and Moder with trend to Amphi) may also indicate a high small-scale variability of humus forms in large parts of the study area corresponding to our findings at the local scale. Models at the slope and landscape scale do not explicitly account for spatial variations of humus forms at the local scale due to the aggregation of humus form samples per study site [3]. Therefore, a high local-scale variation of Moder, Mull and Amphi leads to the prediction of an intermediate dominant humus form class in the landscape-scale model. Thus, the results of this study highlight that local-scale studies are also necessary in order to enhance the understanding of landscape-scale patterns of humus forms. 


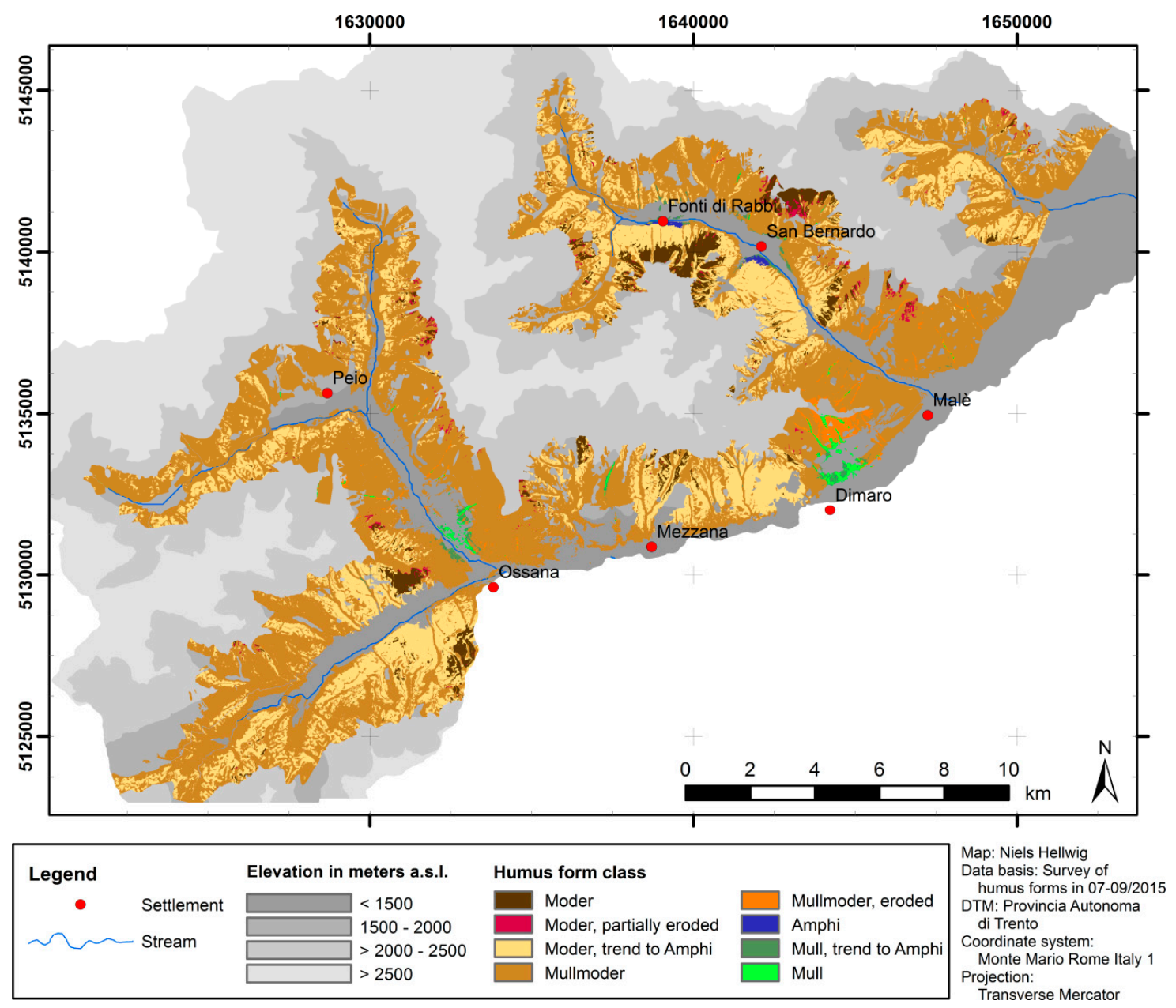

Figure 6. Predicted humus form classes at the landscape scale.

Slope-scale and landscape-scale predictions of humus forms in this study were based on random forest models with ordinary kriging of the model residuals. The random forest models integrate the correlation of humus forms with environmental influences. However, these models explain only a low share of humus forms sampled at the slope and landscape scale. Therefore, kriging of the model residuals was applied to include the spatial variability that is not explained by the random forest models [3]. Another approach to model spatial patterns of humus forms at the landscape scale on the basis of fuzzy logic was introduced by Hellwig et al. [28]. The patterns predicted by fuzzy logic models were generally coarser, as they only included samples from six investigation sites chosen with expert knowledge. As compared to those fuzzy logic models, we applied random forest plus kriging of the model residuals as a data-mining approach relying on a larger sampling set.

The validity of the model results is limited, especially at the landscape scale. Relying on 90 investigation sites across the study area, random forest models still had low explained variances and ordinary kriging of the model residuals did not account for local to slope-scale variations. Moreover, it remains unclear which additional factors and processes (e.g., land use history) might be related to the patterns modeled by kriging of the model residuals. At the slope scale, the explanatory power of random forest models was higher than at the landscape scale and kriging of the residuals enhanced the model significantly due to a dense net of investigation sites [3].

It remains a future challenge to understand and model the relationship between spatial patterns at different scales in order to provide flexible methods for upscaling and downscaling of soil ecological patterns [62]. This also includes advances in the understanding of underlying ecological processes [63]. 
Presuming an enhanced understanding of cross-scale relationships, process-based simulation model approaches provide a valuable tool to integrate ecological processes and spatial patterns $[64,65]$.

\section{Conclusions}

Due to their indicator function, the analyses of humus forms are important to early detect changes of soil ecological processes and associated vegetation shifts (e.g., in the context of climate change or changing forest management practices). This study highlights the need for local and slope-scale studies in order to enhance the understanding of environmental influences on soil ecological patterns and processes in montane and subalpine forests and to allow for reliable large-scale predictions of humus forms.

Spatial patterns of forest humus forms investigated in this study are related to different environmental factors depending on the spatial scale. At the slope and landscape scales, all humus form classes (Mull, Mullmoder, Moder, Amphi and Eroded Moder) are found. At the local scale, on the contrary, the presence of forest humus forms depends on the micro-topographical position. For example, at high elevation on north-facing slopes, the only forest humus form is Moder, independently of local site factors, whereas humus forms at low elevations and on south-facing slopes show a high local variability.

Local-scale patterns of humus forms generally coincide with variations of micro-topography and ground cover, for instance driven by erosion and accumulation along the slope and the distribution of light and shadow within the forest. By contrast, patterns at the slope scale show a distinct correlation with slope exposure and elevation (see Figure 5). This correlation appears to be mainly controlled by topoclimatic effects. At the landscape scale, the relationship between the distribution of forest humus forms and environmental factors is weak. These patterns are likely to be a result of both a wide range of environmental influences and cross-scale effects arising from patterns at the local and slope scales.

Overall, the performance of spatial models at the slope scale is better than at the landscape scale. Random forest models at the slope scale have higher explanatory power as compared to the landscape scale, since the net of investigation sites is much denser. Deviations of actual humus forms from model predictions may be high especially at the landscape scale, as these models do not account for local to slope-scale variations of humus forms.

Supplementary Materials: The following are available online at http:/ /www.mdpi.com/2071-1050/11/1/48/s1, Figure S1: Distribution of forest tree species in the study area, Figure S2: Predicted distribution of the presence of organic layers above the mineral soil at the landscape scale, Figure S3: Predicted distribution of the biogenic soil structure in the mineral soil at the landscape scale, Figure S4: Variograms used for kriging of the model residuals from random forest, Table S1: Humus forms (according to [34,35]) sampled at 30 sites within the study area (A1-A30), Table S2: Humus form classes sampled at different ground cover types at the local scale (sites N1-N3 and S6-S8), Table S3: Predicted areas covered by humus form classes as derived from spatial models at the slope and landscape scale (in ha).

Author Contributions: Conceptualization, N.H. and G.B.; methodology, N.H.; formal analysis, N.H.; investigation, N.H., D.T., G.S., K.A., U.G. and M.E.; Writing-Original Draft preparation, N.H.; Writing-Review and Editing, N.H. and G.B.; supervision, G.B. and J.-M.G.; funding acquisition, G.B., M.E. and J.-M.G.

Funding: This research was realized in the context of the D.A.CH. project DecAlp and funded by the German Research Foundation (DFG), grant number BR 1106/23-1, Swiss National Science Foundation (SNF), grant number 205321L_141186, and Austrian Science Fund (FWF).

Acknowledgments: The authors thank all colleagues in the project for the excellent cooperation. We also thank Dott. Fabio Angeli (Ufficio Distrettuale Forestale di Malè) and the Stelvio National Park for supporting the field work. We acknowledge support by Deutsche Forschungsgemeinschaft (DFG) and Open Access Publishing Fund of Osnabrück University.

Conflicts of Interest: The authors declare no conflict of interest. The funders had no role in the design of the study; in the collection, analyses, or interpretation of data; in the writing of the manuscript, or in the decision to publish the results. 


\section{References}

1. Ponge, J.F. Plant-soil feedbacks mediated by humus forms: A review. Soil Biol. Biochem. 2013, 57, $1048-1060$. [CrossRef]

2. Ponge, J.F. Humus forms in terrestrial ecosystems: A framework to biodiversity. Soil Biol. Biochem. 2003, 35, 935-945. [CrossRef]

3. Hellwig, N.; Gómez-Brandón, M.; Ascher-Jenull, J.; Bardelli, T.; Anschlag, K.; Fornasier, F.; Pietramellara, G.; Insam, H.; Broll, G. Humus Forms and Soil Microbiological Parameters in a Mountain Forest: Upscaling to the Slope Scale. Soil Syst. 2018, 2, 12. [CrossRef]

4. Bardelli, T.; Gómez-Brandón, M.; Ascher-Jenull, J.; Fornasier, F.; Arfaioli, P.; Francioli, D.; Egli, M.; Sartori, G.; Insam, H.; Pietramellara, G. Effects of slope exposure on soil physico-chemical and microbiological properties along an altitudinal climosequence in the Italian Alps. Sci. Total Environ. 2017, 575, 1041-1055. [CrossRef] [PubMed]

5. Gómez-Brandón, M.; Ascher-Jenull, J.; Bardelli, T.; Fornasier, F.; Sartori, G.; Pietramellara, G.; Arfaioli, P.; Egli, M.; Beylich, A.; Insam, H.; et al. Ground cover and slope exposure effects on micro- and mesobiota in forest soils. Ecol. Indic. 2017, 80, 174-185. [CrossRef]

6. Hellwig, N.; Graefe, U.; Tatti, D.; Sartori, G.; Anschlag, K.; Beylich, A.; Gobat, J.M.; Broll, G. Upscaling the spatial distribution of enchytraeids and humus forms in a high mountain environment on the basis of GIS and fuzzy logic. Eur. J. Soil Biol. 2017, 79, 1-13. [CrossRef]

7. Ettema, C.H.; Wardle, D.A. Spatial soil ecology. Trends Ecol. Evol. 2002, 17, 177-183. [CrossRef]

8. O’Brien, S.L.; Gibbons, S.M.; Owens, S.M.; Hampton-Marcell, J.; Johnston, E.R.; Jastrow, J.D.; Gilbert, J.A.; Meyer, F.; Antonopoulos, D.A. Spatial scale drives patterns in soil bacterial diversity. Environ. Microbiol. 2016, 18, 2039-2051. [CrossRef]

9. Bednorz, F.; Reichstein, M.; Broll, G.; Holtmeier, F.K.; Urfer, W. Humus Forms in the Forest-Alpine Tundra Ecotone at Stillberg (Dischmatal, Switzerland): Spatial Heterogeneity and Classification. Arct. Antarct. Alp. Res. 2000, 32, 21-29. [CrossRef]

10. Hiller, B.; Müterthies, A.; Holtmeier, F.K.; Broll, G. Investigations on Spatial Heterogeneity of Humus Forms and Natural Regeneration of Larch (Larix decidua Mill.) and Swiss Stone Pine (Pinus cembra L.) in an Alpine Timberline Ecotone (Upper Engadine, Central Alps, Switzerland). Geogr. Helv. 2002, 57, 81-90. [CrossRef]

11. Anschlag, K.; Tatti, D.; Hellwig, N.; Sartori, G.; Gobat, J.M.; Broll, G. Vegetation-based bioindication of humus forms in coniferous mountain forests. J. Mt. Sci. 2017, 14, 662-673. [CrossRef]

12. Ascher, J.; Sartori, G.; Graefe, U.; Thornton, B.; Ceccherini, M.T.; Pietramellara, G.; Egli, M. Are humus forms, mesofauna and microflora in subalpine forest soils sensitive to thermal conditions? Biol. Fertil. Soils 2012, 48, 709-725. [CrossRef]

13. Badía, D.; Ruiz, A.; Girona, A.; Martí, C.; Casanova, J.; Ibarra, P.; Zufiaurre, R. The influence of elevation on soil properties and forest litter in the Siliceous Moncayo Massif, SW Europe. J. Mt. Sci. 2016, 13, 2155-2169. [CrossRef]

14. Bayranvand, M.; Kooch, Y.; Hosseini, S.M.; Alberti, G. Humus forms in relation to altitude and forest type in the Northern mountainous regions of Iran. For. Ecol. Manag. 2017, 385, 78-86. [CrossRef]

15. Bojko, O.; Kabala, C. Organic carbon pools in mountain soils-Sources of variability and predicted changes in relation to climate and land use changes. Catena 2017, 149, 209-220. [CrossRef]

16. Dobrowski, S.Z. A climatic basis for microrefugia: The influence of terrain on climate. Glob. Chang. Biol. 2011, 17, 1022-1035. [CrossRef]

17. Egli, M.; Poulenard, J. Soils of Mountainous Landscapes. In The International Encyclopedia of Geography: People, the Earth, Environment, and Technology; Richardson, D., Castree, N., Goodchild, M.F., Kobayashi, A., Liu, W., Marston, R.A., Eds.; Wiley: New York, NY, USA, 2017; ISBN 978-0-470-65963-2. [CrossRef]

18. Pelletier, J.D.; Barron-Gafford, G.A.; Gutiérrez-Jurado, H.; Hinckley, E.-L.S.; Istanbulluoglu, E.; McGuire, L.A.; Niu, G.-Y.; Poulos, M.J.; Rasmussen, C.; Richardson, P.; et al. Which way do you lean? Using slope aspect variations to understand Critical Zone processes and feedbacks. Earth Surf. Process. Landf. 2018, 43, 1133-1154. [CrossRef] 
19. Webster, R. The development of pedometrics. Geoderma 1994, 62, 1-15. [CrossRef]

20. Heuvelink, G.B.M.; Webster, R. Modelling soil variation: Past, present, and future. Geoderma 2001, 100, 269-301. [CrossRef]

21. Gessler, P.E.; Moore, I.D.; McKenzie, N.J.; Ryan, P.J. Soil-landscape modelling and spatial prediction of soil attributes. Int. J. Geogr. Inf. Syst. 1995, 9, 421-432. [CrossRef]

22. McBratney, A.B.; Mendonça Santos, M.L.; Minasny, B. On digital soil mapping. Geoderma 2003, 117, 3-52. [CrossRef]

23. Grunwald, S. Multi-criteria characterization of recent digital soil mapping and modeling approaches. Geoderma 2009, 152, 195-207. [CrossRef]

24. Sanchez, P.A.; Ahamed, S.; Carré, F.; Hartemink, A.E.; Hempel, J.; Huising, J.; Lagacherie, P.; McBratney, A.B.; McKenzie, N.J.; Mendonça-Santos, M.L.; et al. Digital Soil Map of the World. Science 2009, 325, 680-681. [CrossRef] [PubMed]

25. Arrouays, D.; McKenzie, N.; Hempel, J.; Richer de Forges, A.; McBratney, A.B. (Eds.) GlobalSoilMap: Basis of the Global Spatial Soil Information System; CRC Press: London, UK, 2014; ISBN 978-1-138-00119-0.

26. Hengl, T.; de Jesus, J.M.; Heuvelink, G.B.M.; Ruiperez Gonzalez, M.; Kilibarda, M.; Blagotić, A.; Shangguan, W.; Wright, M.N.; Geng, X.; Bauer-Marschallinger, B.; et al. SoilGrids250m: Global gridded soil information based on machine learning. PLoS ONE 2017, 12, e0169748. [CrossRef] [PubMed]

27. Aberegg, I.; Egli, M.; Sartori, G.; Purves, R. Modelling spatial distribution of soil types and characteristics in a high Alpine valley (Val di Sole, Trentino, Italy). Studi Trent. Sci. Nat. 2009, 85, 39-50. [CrossRef]

28. Hellwig, N.; Anschlag, K.; Broll, G. A fuzzy logic based method for modeling the spatial distribution of indicators of decomposition in a high mountain environment. Arct. Antarct. Alp. Res. 2016, 48, 623-635. [CrossRef]

29. Von Seidlein, C. Petrographie und Struktur des Ostalpinen Altkristallins Südlich des Ultentales (Trentino, Nord-Italien). Ph.D. Thesis, Ludwig-Maximilians-Universität München, Munich, Germany, 2000.

30. Hellwig, N. Spatial Patterns of Humus Forms, Soil Organisms and Soil Biological Acitivity at High Mountain Forest Sites in the Italian Alps. Ph.D. Thesis, Institute of Geography, Osnabrück University, Osnabrück, Germany, 2018. Available online: https://repositorium.ub.uni-osnabrueck.de/handle/urn:nbn:de:gbv: 700-20181024676?locale=en (accessed on 1 November 2018).

31. Sboarina, C.; Cescatti, A. Il clima del Trentino-Distribuzione Spaziale Delle Principali Variabili Climatiche, Report Centro Ecologia Alpina 33; Centro di Ecologia Alpina: Sardagna (Trento), Italy, 2004; pp. 1-20.

32. Sartori, G.; Mancabelli, A. Carta dei suoli del Trentino: Scala 1:250.000. Museo Tridentino di Scienze Naturali di Trento; Centro di Ricerca per 1'Agrobiologia e la Pedologia di Firenze: Trento, Italy, 2009.

33. IUSS Working Group WRB. World Reference Base for Soil Resources 2006; World Soil Resources Report 103; FAO: Rome, Italy, 2006.

34. Ad-hoc-AG Boden. Bodenkundliche Kartieranleitung, 5th ed.; E. Schweizerbart'sche Verlagsbuchhandlung: Hannover, Germany, 2005; ISBN 978-3-510-95920-4.

35. Graefe, U. Gibt es in Deutschland die Humusform Amphi? Mitt. Dtsch. Bodenkd. Ges. 2007, 110, 459-460.

36. Green, R.N.; Trowbridge, R.L.; Klinka, K. Towards a Taxonomic Classification of Humus Forms. For. Sci. Monogr. 1993, 29, 1-49.

37. Jabiol, B. French humus forms classification: What's new in the Référentiel pédologique 2008? Studi Trent. Sci. Nat. 2009, 85, 153-156.

38. Zanella, A.; Ponge, J.-F.; de Waal, R.; Ferronato, C.; De Nobili, M.; Juilleret, J. Humusica 1, article 3: Essential bases - Quick look at the classification. Appl. Soil Ecol. 2018, 122, 42-55. [CrossRef]

39. Egli, M.; Mirabella, A.; Sartori, G.; Zanelli, R.; Bischof, S. Effect of north and south exposure on weathering rates and clay mineral formation in Alpine soils. Catena 2006, 67, 155-174. [CrossRef]

40. Minasny, B.; McBratney, A.B. A conditioned Latin hypercube method for sampling in the presence of ancillary information. Comput. Geosci. 2006, 32, 1378-1388. [CrossRef]

41. Breiman, L. Random Forests. Mach. Learn. 2001, 45, 5-32. [CrossRef]

42. Heung, B.; Bulmer, C.E.; Schmidt, M.G. Predictive soil parent material mapping at a regional-scale: A Random Forest approach. Geoderma 2014, 214-215, 141-154. [CrossRef] 
43. Guo, P.T.; Li, M.F.; Luo, W.; Tang, Q.F.; Liu, Z.W.; Lin, Z.M. Digital mapping of soil organic matter for rubber plantation at regional scale: An application of random forest plus residuals kriging approach. Geoderma 2015, 237, 49-59. [CrossRef]

44. Hengl, T.; Heuvelink, G.B.M.; Kempen, B.; Leenaars, J.G.B.; Walsh, M.G.; Shepherd, K.D.; Sila, A.; MacMillan, R.A.; Mendes de Jesus, J.; Tamene, L.; et al. Mapping Soil Properties of Africa at $250 \mathrm{~m}$ Resolution: Random Forests Significantly Improve Current Predictions. PLoS ONE 2015, 10, e0125814. [CrossRef] [PubMed]

45. Liaw, A.; Wiener, M. Classification and Regression by randomForest. R News 2002, 2, 18-22.

46. R Core Team. R: A Language and Environment for Statistical Computing; R Foundation for Statistical Computing: Vienna, Austria, 2018; Available online: http:/ / www.R-project.org/ (accessed on 14 October 2018).

47. Zevenbergen, L.W.; Thorne, C.R. Quantitative analysis of land surface topography. Earth Surf. Process. Landf. 1987, 12, 47-56. [CrossRef]

48. Böhner, J.; Antonic, O. Land surface parameters specific to topo-climatology. In Geomorphometry-Concepts, Software, Applications; Hengl, T., Reuter, H.I., Eds.; Elsevier: Amsterdam, The Netherlands, 2009; pp. 195-226, ISBN 978-0-12-374345-9. [CrossRef]

49. Böhner, J.; Köthe, R.; Conrad, O.; Gross, J.; Ringeler, A.; Selige, T. Soil regionalisation by means of terrain analysis and process parameterization. In Soil Classification 2001; Micheli, E., Nachtergaele, F., Montanarella, L., Eds.; The European Soil Bureau, Joint Research Centre: Ispra, Italy, 2002; pp. $213-222$.

50. Moore, I.D.; Grayson, R.B.; Ladson, A.R. Digital terrain modelling: A review of hydrological, geomorphological, and biological applications. Hydrol. Process. 1991, 5, 3-30. [CrossRef]

51. Freeman, T.G. Calculating catchment area with divergent flow based on a regular grid. Comput. Geosci. 1991, 17, 413-422. [CrossRef]

52. Friedrich, K. Multivariate distance methods for geomorphographic relief classification. In Land Information Systems-Developments for Planning the Sustainable Use of Land Resources; Heineke, H.J., Eckelmann, W., Thomasson, A.J., Jones, R.J.A., Montanarella, L., Buckley, B., Eds.; The European Soil Bureau, Joint Research Centre: Ispra, Italy, 1998; pp. 259-266.

53. Malone, B.P.; McBratney, A.B.; Minasny, B. Spatial Scaling for Digital Soil Mapping. Soil Sci. Soc. Am. J. 2013, 77, 890-902. [CrossRef]

54. Pachepsky, Y.; Hill, R.L. Scale and scaling in soils. Geoderma 2017, 287, 4-30. [CrossRef]

55. Levin, S.A. The problem of pattern and scale in ecology. Ecology 1992, 73, 1943-1967. [CrossRef]

56. Tatti, D.; Fatton, V.; Sartori, L.; Gobat, J.-M.; Le Bayon, R.-C. What does 'lignoform' really mean? Appl. Soil Ecol. 2018, 123, 632-645. [CrossRef]

57. Spielvogel, S.; Prietzel, J.; Kögel-Knabner, I. Stand scale variability of topsoil organic matter composition in a high-elevation Norway spruce forest ecosystem. Geoderma 2016, 267, 112-122. [CrossRef]

58. Egli, M.; Sartori, G.; Mirabella, A.; Favilli, F.; Giaccai, D.; Delbos, E. Effect of north and south exposure on organic matter in high Alpine soils. Geoderma 2009, 149, 124-136. [CrossRef]

59. Egli, M.; Hafner, S.; Derungs, C.; Ascher-Jenull, J.; Camin, F.; Sartori, G.; Raab, G.; Bontempo, L.; Paolini, M.; Ziller, L.; et al. Decomposition and stabilisation of Norway spruce needle-derived material in Alpine soils using a ${ }^{13}$ C-labelling approach in the field. Biogeochemistry 2016, 131, 321-338. [CrossRef]

60. Hellwig, N.; Anschlag, K.; Broll, G. Modellgestützte Analyse räumlicher Dekompositionsmuster im Hochgebirge. 2017. Available online: http://eprints.dbges.de/1232/1/Hellwig\%20et\%20al_2017_DBG\% 20eprints_Dekompositionsmuster\%20R\%C3\%A4umliche\%20Modelle\%20Hochgebirge.pdf (accessed on 6 October 2018).

61. Bebi, P.; Seidl, R.; Motta, R.; Fuhr, M.; Firm, D.; Krumm, F.; Conedera, M.; Ginzler, C.; Wohlgemuth, T.; Kulakowski, D. Changes of forest cover and disturbance regimes in the mountain forests of the Alps. For. Ecol. Manag. 2017, 388, 43-56. [CrossRef]

62. Scholes, R.J. Taking the Mumbo Out of the Jumbo: Progress Towards a Robust Basis for Ecological Scaling. Ecosystems 2017, 20, 4-13. [CrossRef]

63. Urban, D.L. Modeling ecological processes across scales. Ecology 2005, 86, 1996-2006. [CrossRef] 
64. Cuddington, K.; Fortin, M.J.; Gerber, L.R.; Hastings, A.; Liebhold, A.; O'Connor, M.; Ray, C. Process-based models are required to manage ecological systems in a changing world. Ecosphere 2013, 4, 20. [CrossRef]

65. Sarmento Cabral, J.; Valente, L.; Hartig, F. Mechanistic simulation models in macroecology and biogeography: State-of-art and prospects. Ecography 2017, 40, 267-280. [CrossRef] 